\title{
THE CURRENT UNSUSTAINABLE BOOM IN THE ARGENTINE ECONOMY
}

\author{
ADRIÁN RAVIER*
}

Fecha de recepción: 7 de febrero de 2013.

Fecha de aceptación: 25 de junio de 2013.

Since 2010, Paul Krugman has been suggesting that Greece, Spain, Ireland and other European countries should consider abandoning the euro and devalue their currencies in order to solve their fiscal difficulties. In January of 2011 Krugman repeated the same prescription, but added that the Argentine default and devaluation of 2001-2002 should be taken as an example of what Greece and other European countries in trouble should do to escape the crisis in which they are immersed.

In Krugman's own words:

Some economists, myself included, look at Europe's woes and have the feeling that we've seen this movie before, a decade ago on another continent - specifically, in Argentina. [...] Argentina didn't simply default on its foreign debt; it also abandoned its link to the dollar, allowing the peso's value to fall by more than two-thirds. And this devaluation worked: from 2003 onward, Argentina experienced a rapid export-led economic rebound. (Krugman, 2011a). ${ }^{1}$

The Argentinian government could not resist the temptation to use the unfortunate words of this Nobel Prize winner to congratulate themselves on the success of policies implemented over the last decade.

* The author obtained his Ph.D. in Economics in the Rey Juan Carlos University in Madrid. He is a Professor of Economics at the School of Business of the Francisco Marroquín University (aravier@ufm.edu). The author is indebted to Andrew Reed for his comments on an earlier draft of this paper which helped improve the structure and clarity of the argument. The author retains sole responsibility for any remaining shortcomings.

1 See also Krugman 2010, 2011b, 2011c, 2012. 
My objective is to try to clarify what happened in Argentina's recent economic history, in order to shed light on a current and controversial topic in the field of economic policy.

\author{
I \\ «MENEMISM» (1989-1999)
}

After the return to democracy in 1983, the administration of President Ricardo Alfonsín experienced serious economic difficulties that ended with his resignation in the midst of uncontrolled hyperinflation in 1989 (Hanke and Krus 2012).

The Peronist Carlos Menem took office in these circumstances and, after two years of blunders, he installed an economic team led by Domingo Cavallo that found a way out of the impasse. As the fiscal deficit could no longer be financed by issuing money and the country was without access to external credit, revenue could only be obtained through the privatization of loss-making state-owned companies. Between 1991 and 1993, Argentina pegged the peso to the dollar (Hanke and Schuler 2002), privatized lossmaking state owned companies, agreed to the Brady debt restructuring Plan (Vásquez, 1996), came out of default, joined the free-trade area MERCOSUR and began to plan the privatization of the pension system (Figure 1).

Argentina was unable to completely eliminate its fiscal deficit, but in 1993 the extraordinary income earned from privatization provided some relief. After 1994, government spending and the fiscal deficit began to grow but were financed with external credit (Guido and Lazzari 2003).

Argentina's economy enjoyed stability, but as long as the fiscal deficit remained the country's growth depended on increasing foreign debt, which was only obtainable with the International Monetary Fund as a guarantor (E.A. Bruno, 2006).

Surprisingly, Menem reached an agreement with Ricardo Alfonsin that enabled him to amend the Constitution and seek reelection in 1995. Once he was re-elected, complications began to arise.

The 1995 Tequila crisis, the Asian crisis of 1997, the Russian crisis of 1998 and the Brazilian devaluation of 1999 were all serious 
FIGURE 1

\section{HYPERINFLATION IN ARGENTINA}

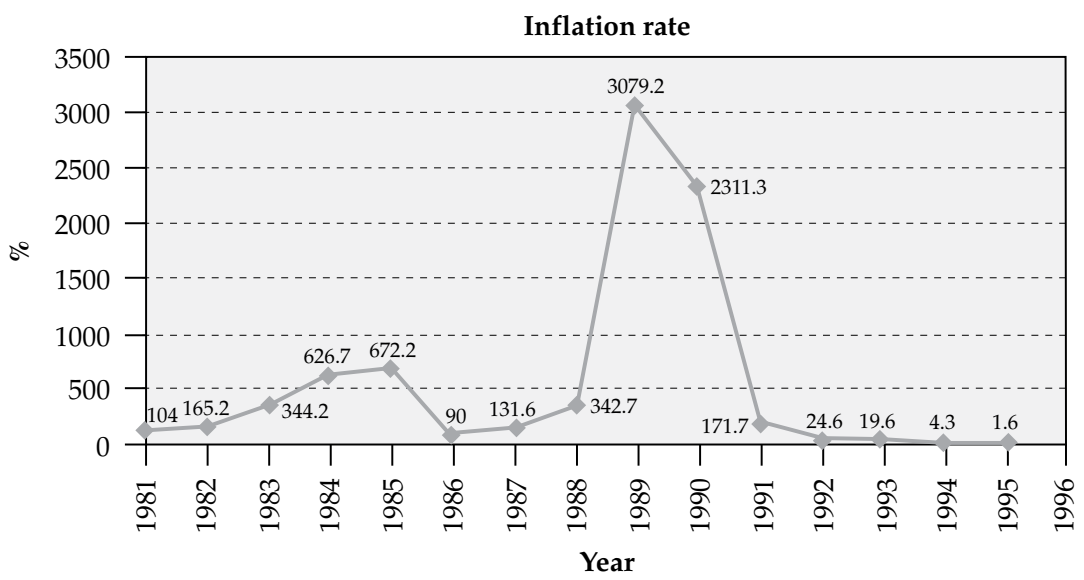

setbacks for Argentina's economy, and it was on the brink of collapse by the third quarter of 1998 (Hanke 2002, Calvo, Izquierdo and Talvi 2003).

\section{II}

BETWEEN «MENEMISM»AND «KIRSCHNERISM» (1999-2003)

In 1999, the «Alliance» led by Fernando De la Rua won the elections. A decision was made to maintain the convertibility system, but the external adversities and the consequent strengthening of the dollar made it impossible to control the fiscal deficit. ${ }^{2}$

2 «Signs of recovery appeared in late 1999 and early 2000, but the incoming de la Rúa government choked the recovery by enacting large tax increases that took effect at the start of 2000. The government (and the IMF, which lent support to the government's program) thought the tax increases were necessary to reduce the budget deficit. Instead, tax collections fell. When Domingo Cavallo became minister of the economy in March 2001, he pushed through a financial transaction tax, which was increased in August to its current rate of 0.6 percent on bank debits and credits. Although the tax rate may appear low, it is not.» (Hanke 2002). 
After another early resignation in December 2001 followed by a rapid succession of presidents and another declaration of default, Eduardo Duhalde decided to abandon convertibility, forcibly transform domestic dollar deposits into pesos, and devalue the currency. ${ }^{3}$

Argentina's GDP fell by more than $10 \%$ in 2002, and a process of exchange rate adjustment began which saw the peso/dollar rate move from parity (1-1) to $3-1$ in a controlled manner. ${ }^{4}$

\section{III «KIRCHNERISM» (2003-2011)}

In 2003 elections were held and Nestor Kirchner came to power with less than $23 \%$ of the votes. Argentina's economy had just started to recover and was in the process of emerging from a deep crisis. As the result of the sharp devaluation, local wages were very low in dollar terms, and Argentine industries became competitive abroad.

Then the international context changed: 1) There was an absence of international shocks until the American sub-prime crisis of $2008 ; 2)$ the United States abandoned the strong dollar and short term interest rates turned negative in real terms (Ravier and Lewin 2012); 3) China became the world's factory, and a source of demand for Argentina's commodities which raised prices to record levels (Figure 2); 4) In sharp contrast to its normal policy, Brazil allowed its currency to float, which improved Argentina's trade balance with that country.

\footnotetext{
${ }^{3}$ Conventional wisdom in Argentina held that linking the peso to the dollar somehow «overvalued» it, making the Argentine economy uncompetitive and stifling economic growth. Hanke and Schuler (2002) point out that before central bankers accept this conventional wisdom they should examine it carefully. The dollar-linked monetary system Argentina abandoned was never fully understood, either in its strengths or its weaknesses. An alternative solution to convertibility would have been dollarization. See Hanke (1999).

4 The three factors contributing to this devastating crisis were fiscal inconsistency, lack of flexibility and external shocks. See R. López Murphy, D. Artana and F. Navajas 2003.
} 


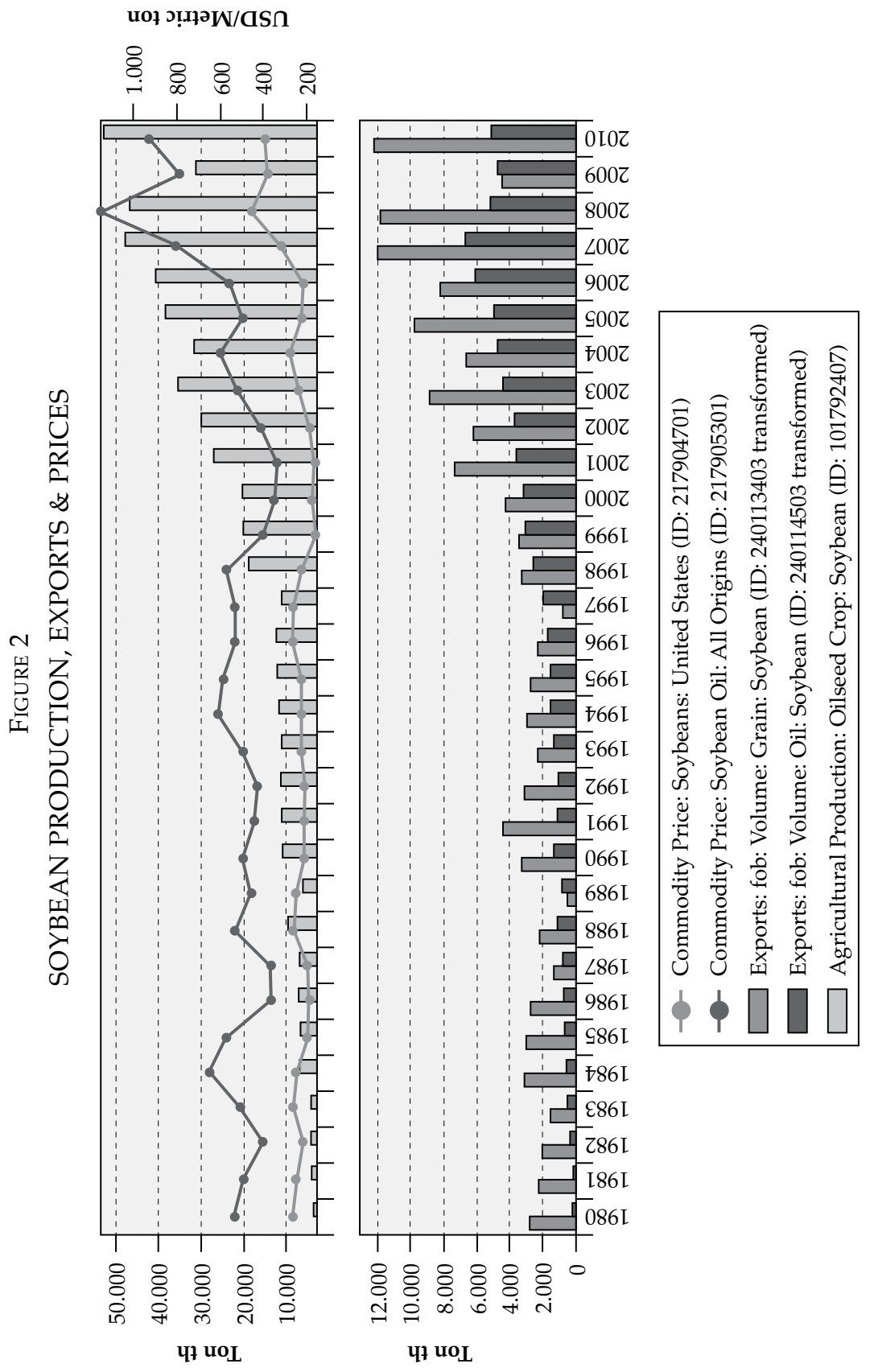


In this context, Argentina's economy began a rapid recovery and some authors recalled the nickname given to Argentina in the late 19th and early $20^{\text {th }}$ centuries: «the Granary of the World». The government, however, hindered the process. ${ }^{5}$

First it became a dependent of the rural sector as it took advantage of the export tax amounting to about $35 \%$ of the value of export. Revenue from this source rose over time due to the upward spiral of commodity prices and export volumes. Conflicts with the sector were an obvious consequence. The resulting «war with the rural sector» will stand out as one of the most important factors in Argentina's history over the past decade (Schweimler 2008).

Second, Nestor Kirchner, and later his wife, understood that raising the nominal exchange rate (devaluing the peso) would make domestic industry more competitive while at the same time increasing export withholding tax revenues. This led to a gradual rise in the nominal exchange rate from 3-1 in 2003 to approximate 5-1 in early 2013, but with an unofficial («blue») dollar rate exchange rate that now exceeds 7 pesos.

The real exchange rate, therefore, is again back at the same level as it was at the end of 2001, which means that industries «created» in the last decade will find it difficult to survive (Figure 3).

Third, and linked to the aforementioned points, it was decided to impose an inflation tax (issue money) to help finance the state budget. This is, in short, the main cause of the escalating inflation that private analysts estimate at between 22 and 30\% (as opposed to the official data of Indec which puts it at around 10\%) (O'Grady 2012, Turner 2011).

Fourth, the government re-nationalized pensions, on the basis that this allowed it to use both the funds appropriated from private plans to pay current pension obligations and the «retirement savings» of workers remitted as pension premiums as though they were taxes (Niemietz 2009).

Fifth, the government destroyed the last vestiges of the independence of the Central Bank and demanded large amounts

5 See García Hamilton (2006) Historical Reflections on the Splendor and Decline of Argentina. 
FIGURE 3

REAL EXCHANGE RATE IN ARGENTINA (BASE DEC. 2001)

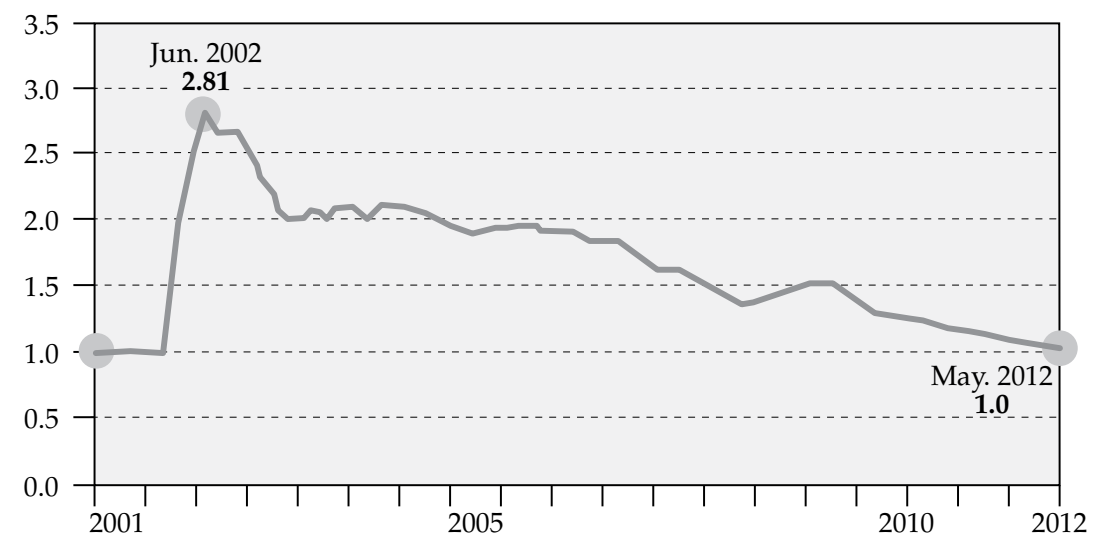

Source: IERAL.

of dollar reserves be used to pay down commitments to the International Monetary Fund, thereby avoiding any audits by multilateral credit agencies (Katz 2005).

Sixth, it re-nationalized Repsol-YPF, ${ }^{6}$ and thus tried to follow the path of Venezuela, increasing production of crude oil and its derivatives in order to increase the resource tax revenues available to sustain the "Kirchner ("K") Scheme» (Moffet and Turner 2012).

These measures financed an increase in the level of consolidated public spending from $30 \%$ to $45 \%$ of GDP, as shown in Figure 4 . Political analysts detail how the government developed a complicated arrangement which required the support of local governors and mayors for the Kirchner scheme before any delivery of discretionary funds occurred. Alleged cases of corruption may even extend to buying the votes of members of congress and Senators to support key congressional laws.

6 Founded in 1922, YPF (Yacimientos Petrolíferos Fiscales, («Treasury Petroleum Fields») was the first oil company in the world established as a state enterprise. In the middle of hyperinflation and a huge fiscal deficit, Menem start to think in a privatization of YPF - along with other public services - and this took place in 1993. In 1999 the Spanish firm Repsol bought 98\% of YPF. After some years of declining investments which were the inevitable response to price controls, YPF-Repsol was expropriated and re-nationalized in May 2012. 


\section{FIGURE 4}

\section{EVOLUTION OF THE CONSOLIDATED PUBLIC SPENDING RELATIVE TO GDP}

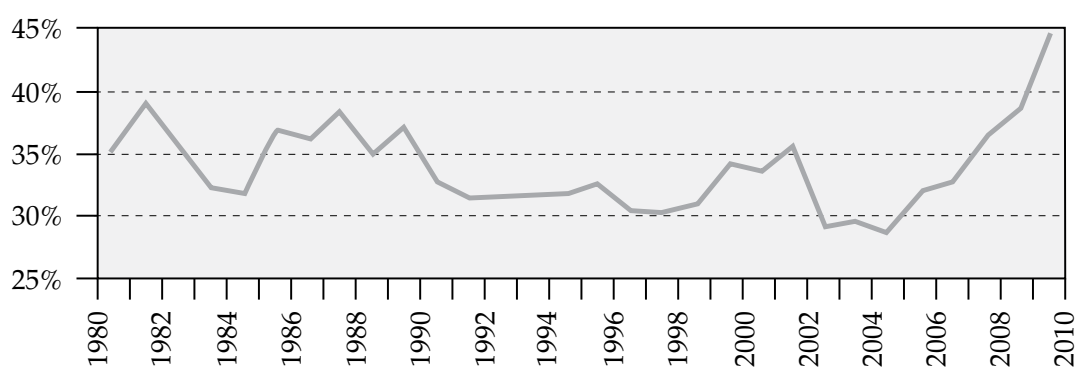

Source: FIEL on data from the National Public Expenditure and Social Programs and the FIEL Macroeconomic Forecasts.

In 2007 elections were held and «Kirchnerism» won again, but this time with Cristina Fernandez de Kirchner as president. However, Néstor Kirchner didn't relinquish power: he accompanied his wife as a virtual Minister of Economy and participated in every decision made at the Casa Rosada or Olivos (the equivalent of the White House and Camp David in Argentina).

Between 2007 and 2011 the same policy direction was followed. The death of Nestor Kirchner in October 2010 left his wife as the ruling party candidate in the next election. Yet another electoral victory began her second term in office which will end in 2015. It seems that when the economy in any country in the world is growing, its society agrees not to «rock the boat».

IV

\section{DIFFICULTIES DURING THE THIRD TERM} OF «KIRCHNERISM»

The main challenges for economic policy over the period 20132015 are 1) economic growth, 2) control of public spending and 3) inflation avoidance.

Although the government emphasizes the «growth» of Argentina's economy during the last decade, strong rates of growth in economic activity have only allowed recovery from the depths 
of the $2001 / 2002$ crisis. This can be demonstrated with reference to GDP per capita and installed capacity utilization.

In the first case, as we can see in Figure 5, when we measure GDP per capita at current prices, it is clear that the economy has only just returned to the peak reached in 1998.

This point is crucial to understanding Krugman's «love affair» with the Kirchner Scheme. In various articles, he uses different graphs of economic growth to prove the «basic fact» that Argentina's growth outperforms that of neighboring Brazil. Juan Carlos Hidalgo demolishes this conclusion by pointing out that:

Krugman's dismissal of economics reporting about Argentina may explain why he doesn't mention the fact that the administration of Cristina Fernández de Kirchner cooks the inflation numbers. The story was recently highlighted in The Economist, which even removed the official inflation figure from its indicators page. As the magazine put it, «Since 2007 Argentina's government has published inflation figures that almost nobody believes.» Apparently, nobody but Paul Krugman.

FIGURE 5

EVOLUTION OF REAL GDP PER CAPITA IN DOLLARS

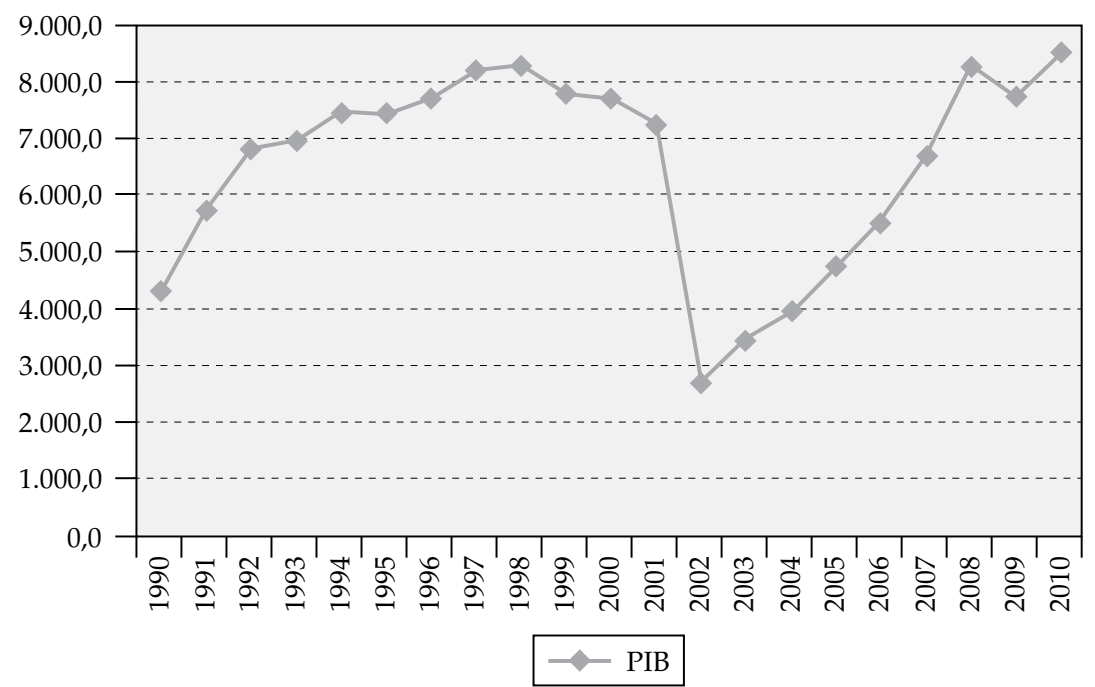

Source: CEI. 
Since Argentina's Consumer Price Index significantly understates true inflation (the official figure for 2011 was $9.7 \%$ whereas private estimates put the figure at $24.4 \%$ ), the country's real GDP is overestimated (Hidalgo, 2012).

In terms of capacity utilization, in 2001 the Argentine economy was operating at below $50 \%$ of capacity, as shown in Figure 6. The recovery of Argentina's economy between 2002 and 2011 saw utilization move up to $80 \%$ of installed capacity, indicating less room for future growth without significant new investment.

Note in Figure 7 the similarity between the 2002-2008 recovery and the one that occurred between 1990 and 1998. Clearly these levels of growth will be difficult to sustain.

This shows an urgent need for the investment required to shift the "production possibility frontier», which alone will permit further improvements in the welfare of Argentinians. However, Argentina's economy has been aligned in recent years with countries such as Cuba, Venezuela, Ecuador and Bolivia, none of which can be expected to contribute the capital required.

Not only that. The flight of capital from the country has been dramatic in recent years, showing that not even Argentinians trust

Figure 6

EVOLUTION OF INDUSTRIAL CAPACITY UTILIZATION (2002-2011)

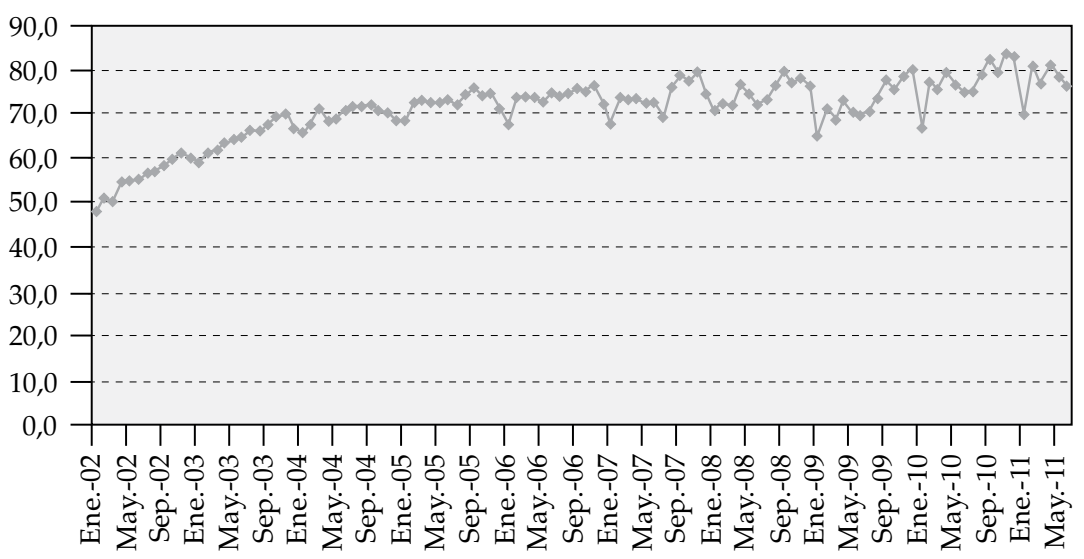

Source: INDEC. 
FIGURE 7

GDP IN MILLION OF DOLLARS (1980-2010)

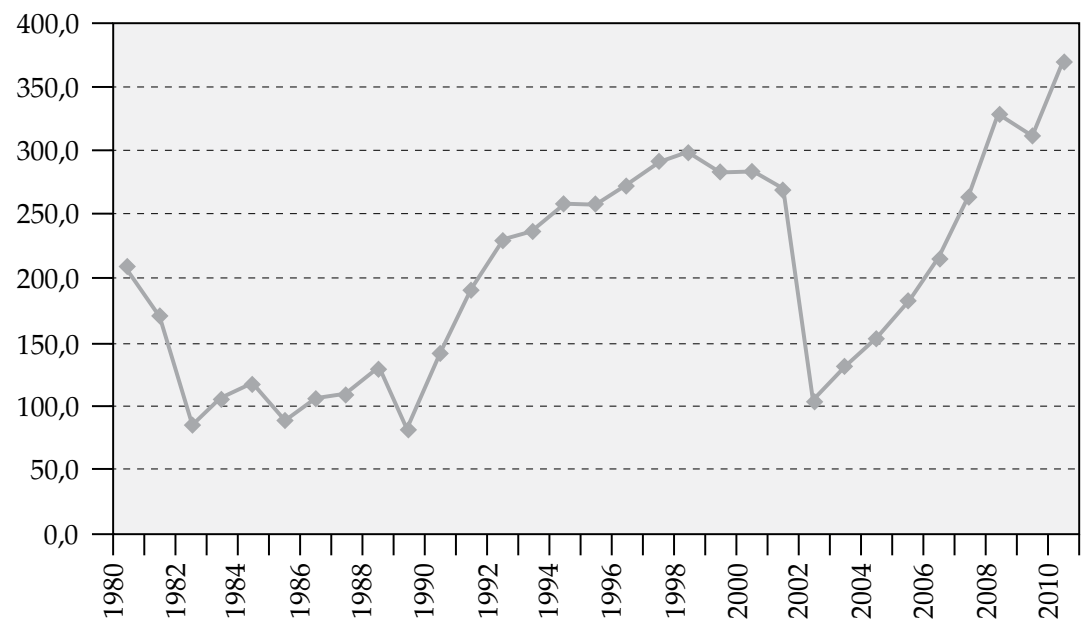

Source: CEI.

their country (Romig 2012). The expropriation of pensions and $\mathrm{YPF}$, and the pressure applied to companies by the government scares away business capital. ${ }^{7}$ The only reason this capital flight has not yet registered as a serious financial problem for the country is the strong inflow of foreign currency generated by soybean exports.

With regard to public spending it is clear that Argentina exceeds levels that can be financed with taxes. The difference is financed by printing money and dipping into private pension funds and central bank reserves (ANSES and BCRA respectively). This has several implications:

First, the difficulty controlling levels of public spending that are already excessive. Accelerating inflation causes constant union demands for salary increases in both the private and the public sectors.

7 «Argentina often blocks or delays imports to boost its trade surplus and force foreign companies to make their goods here. Last month, the European Union complained that Argentina was limiting imports for around 600 products, according to a report by the World Trade Organization. Argentine trade officials declined to comment for this article» (Turner 2011). 
Second, to maintain the aforementioned acceleration in spending of recent years and thus prevent further union demands requires a steady acceleration in tax revenues, which in turn depends on repeating indefinitely the normally rare coincidence of record crops and commodity prices.

The latter in turn depends on two decisive factors: on the one hand, demand from China, which we conjecture will continue, and secondly, the liquidity policy of the United States, contributing to higher commodity prices (from soybeans to gold). No one can predict how long this second factor will last. On one side are the difficulties faced today by the United States in terms of the «inflation risk» inherent in lax monetary policy. On the other, we have a new announcement of Ben Bernanke at the U.S Federal Reserve that interest rates will be kept at around 0 per cent at least through 2014. This may give the Argentine government a break, but the situation may well change dramatically in $2015 .{ }^{8}$

Third, the acceleration of government spending growth relies on the funds of ANSES, which will be depleted by the frequent «extractions» the government makes from the institution sometime in the next four years (Stang 2011).

Fourth, opinion is currently divided between analysts who think that the reserves held by the Central Bank remain sound and others who believe the quality of the reserves has diminished as the result of a process whereby the government has appropriated reserves in exchange for «junk» bonds (Cachanosky 2005, 2009a, 2009b).

Admittedly, these reserves will also be strengthened if Argentina maintains a favorable trade balance with the world. This is becoming increasingly unlikely, because the real exchange rate (Figure 3) is as «overvalued» today as it was in the 1990s. This threatens not only the trade balance but also the competitiveness of industry which is, consequently, pushing for a further devaluation.

${ }^{8}$ If we consider high commodity prices a consequence of the Fed's monetary policy, then it can be said that the latest Bubble is developing in Latin America, and in Argentina in particular! The «bust» will occur as soon as the Fed moves short term interest rates higher. 
To choose not devaluate the peso compromises competitiveness even further, but devaluation will inevitably accelerate inflation. The dilemma is clear.

\section{$\mathrm{V}$ \\ CONCLUSION}

Argentina recovered from the great depression of 2001/2002 thanks to a favorable international context and despite the government. The latter was the main culprit behind high inflation, lack of investment, unprecedented public spending growth and unsustainable economic growth.

It is difficult to foresee a change in the direction recently adopted by the government between now and 2015. The good news is that some institutions still operate in Argentina, and the Constitution now precludes Cristina Fernandez de Kirchner from a third term as president.

After the next election it will be necessary to reverse the process, dismantle the "K scheme», eliminate export withholding taxes and return public spending to levels that can be sustained by the tax base, estimated to be $20 \%$ of GDP (O'Connor and Vignale 2011). ${ }^{9}$

There are three potential ways to accomplish this. The first is to reduce public spending; however, given the power that unions and "protesters» have attained in recent years, such a policy seems highly unlikely (Morales Solá 2009).

The second is to freeze public spending in nominal terms and allow inflation to do the rest, until it is in line with tax revenue. As in the previous case, this is extremely unlikely given the strength of the unions.

The third is for the government to implement a fiscal rule whereby public spending can only increase at a rate lower than the

${ }^{9}$ If we accept the conclusion reached by R. Lizardo and A.V. Mollick (2009) in an article examining the effect of government consumption on economic growth in 23 Latin American countries over the period 1974-2003, we will appreciate that «increases [decreases] in government consumption lead to unambiguous decreases [increases] in economic growth.» 
increase in revenue. If the international context remains favorable —at least through 2013 and 2014 - this policy may allow time to reverse the trend and solve the problem by taking advantage of revenue growth in the short term. This gradually shrinks the size of the government, and was the mechanism used by Chile to reduce its level of public spending to $18 \%$ of GDP, making it a model for other Latin American countries. ${ }^{10}$

Will this current government have the will to implement a comprehensive reform of the state necessary to avoid another profound crisis? Will the government to take office in 2015 be willing to change the policy that by that date would have been in effect for 12 years? Will the government have time to avoid another depression?

My tentative answer is negative in all three cases. Neither the ruling party proposals, nor those of the opposition, suggest any willingness to change course.

It appears that the most likely scenario for the coming years is: 1) lack of private investment and consequently stagnation of economic growth, with negative effects on job creation; 2) fiscal difficulties that prevent salaries in the public sector from maintaining their purchasing power in real terms; 3 ) successive general strikes, even more widespread lawlessness and riots, all of which require increased public spending to maintain order; and 4) increased reliance on inflation to push government fiscal problems off into the futures that will necessarily result in accelerated inflation. The combined effect of these will be an erosion of per capita incomes and the growth of homelessness and poverty.

The year 2013 is crucial if reforms are to be implemented. What happens beyond this year depends on two factors: 1) the moment at which the favorable international context which has benefited the country in recent years turns adverse, particularly an increase in U.S. interest rates and the end of loose monetary policy (not expected before 2014; and 2) whether or not the Argentinian government manages to reverse the policy it has followed in recent years.

10 See the Economic Freedom Index published annually by The Wall Street Journal and the Heritage Foundation. 
Paul Krugman is wrong in two distinct senses. First, he underestimates the economic and social losses involved in the crisis of 2001/2002. Second, he overestimates the «growth» of Argentina's economy in the period 2003/2011. Yes, Argentina recovered from the previous crisis, but future growth does not start from the pit in which Argentina found itself in 2003, but from the level recently attained. Argentina again offers an example of an «unsustainable boom» and is in the process of losing a unique opportunity for development on which other Latin American countries are capitalizing.

\section{BIBLIOGRAPHICAL REFERENCES}

BRUNO, E.A. (2006): «The Failure of Debt-Based Development: Lessons from Argentina», Cato Journal, vol. 26, n.․․ 2, Spring/ Summer.

CACHANOSKY, R. (2005): «Reservas: valor de mercado y contable» [«Reserves: market value and accounting»], La Nación, october 23.

- (2009a): «Reservas: la contabilidad creativa» [«Reserves: creative accounting»], La Nación, january 4.

- (2009b): «Reservas del Banco Central: no aclaren que oscurecen» [Central Bank Reserves: do not clarify that which they obscure], La Nación, january 16.

Calvo, G.A., IzQuierdo, A. y TAlvi, E. (2003): «Sudden Stops, the Real Exchange Rate, and Fiscal Sustainability: Argentina's Lessons,» NBER Working Papers 9828, National Bureau of Economic Research, Inc.

García Hamilton, J.I. (2005): «Historical Reflections on the Splendor and Decline of Argentina», Cato Journal, vol. 25, n.. 3 .

Guido, P. y LAZZARI, G. (2003): «Apuntes sobre la caída de la economía argentina. (Se puede evitar todo, menos las consecuencias)», [«Notes on the Crash of the Argentine Economy: Everything may be avoided, except the consequences»] $L i-$ bertas, n. 38 , ESEADE, Buenos Aires, may.

HANKe, S.H. (2002): «Argentina's Current Political-Economic Crisis», Congressional Testimony, march 5. 
- (1999): «Dollarization for Argentina», Journal of Applied Corporate Finance, Volume 12, Issue 1, pp. 121-126, Spring.

HANKE, S.H. y KRUS, N. (2009): «World Hyperinflations», Cato Working Paper. n. ${ }^{\circ}$, august 15, 2012. Forthcoming in: Randall Parker and Robert Whaples (eds.) (2013) The Handbook of Major Events in Economic History, London: Routledge Publishing. (expected publication date: Summer 2013).

HANKe, S.H. y SCHUleR, K. (2002): "What went wrong in Argentina?», Central Banking Journal, volume XII, number 3, february.

Hidalgo, J.C. (2012): «Krugman's Love Affair with the Kirchner Model in Argentina», Cato at Liberty, may 7.

KATZ, C. (2005): «The effects of paying off the IMF», National University of Buenos Aires, december 20.

Krugman, P. (2012): «Down Argentina Way», The Conscience of a Liberal, may 3.

- (2011a): «Can Europe be Saved?», The New York Times, january 21.

- (2011b): «Don't Cry for Argentina», The Conscience of a Liberal, june 23.

- (2011c): «Unacceptable Success», The Conscience of a Liberal, october 24 .

- (2010): «Default, Devaluation or What?», The Conscience of a Liberal, may 4.

Lizardo, R. y Mollick, A.V. (2009): "Can Latin America Prosper by Reducing the Size of Government?», Cato Journal, vol. 29, no. 2, Spring/Summer.

López Murphy, R., Artana, D. y Navajas F. (2003): «The Argentine Economic Crisis», Cato Journal, vol. 23, n.ำ 1, Spring/ Summer.

Moffett, M. y Turner, T. (2012): «Argentina to Seize Control of Oil Firm», The Wall Street Journal, april 17.

Morales SOlÁ, J. (2009): «Bajo el gobierno de gremialistas y piqueteros» [«Under the government of unionists and protesters»], La Nación, november 8.

NiEmietz, K. (2009): «The nationalisation of retirement savings accounts in Argentina», Economic Affairs 01 /2009; 29(1): 4953. 
O'Connor, E.A. y Vignale, J. (2011): «Sistema Tributario Argentino. Un análisis comparativo de la contribución por sectores productivos y de la equidad sectorial» [«The Argentine Tax System. A comparative analysis of the contributions of productive sectors and sectoral equity»], Programa de Análisis de Coyuntura-Escuela de Economía, Facultad de Ciencias Económicas, UCA, Buenos Aires, (november).

O'Grady, M.A. (2012): "Kirchner Grabs the Central Bank», The Wall Street Journal, april 1, 2012.

RAVIER, A. y LeWIN, P. (2012): «The Subprime Crisis», The Quaterly Journal of Austrian Economics, vol. 15, n.․․ 1, Spring, pp. 4574.

Romig, S. (2012): «Argentina Stems Capital Flight in Third Quarter by Blocking Dollar Buying», The Wall Street Journal, november 16 .

SCHWEIMLER, D. (2008): «Argentina's farm row turns to crisis», BBC News, june 18.

STANG, S. (2011): «Se usan sin control fondos de la ANSES» [«Uncontrolled use of ANSES funds»], La Nación, Argentina, february 21.

Turner, T. (2011a): «Argentina Fines More Economists Over Inflation Estimates», The Wall Street Journal, april 12.

- (2011b): «In Argentina, Cloudy Trade Policies Hamstring Importers», The Wall Street Journal, december 19.

VÁsquez, I. (1996): «The Brady Plan and Market-based solutions to debt crises», Cato Journal, vol. 16, n.․․ 2 . 